\title{
PENGEMBANGAN SISTEM PENUNJANG KEPUTUSAN PENENTUAN UKT MAHASISWA DENGAN MENGGUNAKAN METODE MOORA STUDI KASUS POLITEKNIK NEGERI MALANG
}

\author{
Syaiful Rokhman ${ }^{1}$, Imam Fahrur Rozi ${ }^{2}$, Rosa Andrie Asmara ${ }^{3}$ \\ Program Studi Teknik Informatika, Jurusan Teknologi Informasi, Politeknik Negeri Malang \\ knupi@polinema.ac.id, ${ }^{1}$ imam.rozi@ polinema.ac.id, ${ }^{3}$ rosa.andrie@ polinema.ac.id
}

\begin{abstract}
Abstrak
Aplikasi Decision Support Systems (DSS) atau Sistem Penunjang Keputusan (SPK) penentuan Uang Kuliah Tunggal (UKT) Mahasiswa Politeknik Negeri Malang adalah aplikasi yang digunakan untuk menentukan kelompok biaya kuliah tunggal yang ditanggung oleh masing mahasiswa Politeknik Negeri Malang aplikasi ini dikembangkan menggunakan bahasa pemrograman PHP, database Mysql dan mengimplementasikan Metode Multi Objective Optimization on the Basis of Ratio Analysis (MOORA) dengan menggunakan metode tersebut dapat memberikan alternatif terbaik dalam penentuan uang kuliah tunggal berdasarkan kemampuan ekonomi mahasiswa.
\end{abstract}

Kata Kunci : UKT, Metode MOORA, alternatif terbaik, DSS, SPK, Politeknik Negeri Malang.

\section{Pendahuluan}

Uang Kuliah Tunggal (UKT) merupakan sistem yang diterapkan dalam pembiayaan perkuliahan yang harus ditanggung oleh mahasiswa Perguruan Tinggi Negeri yang berada di bawah Kementerian Riset, Teknologi, dan Pendidikan Tinggi (Kemenristek Dikti). Dalam hal ini, pembiayaan perkuliahaan tidak seperti pada saat-saat sebelumnya dimana biaya perkuliahan mahasiswa adalah terdiri dari beberapa macam komponen yang terpisah, misalnya SPP, Uang Praktikum, Iuran Orang Tua Mahasiswa (IOM), Uang Ujian Skripsi, Uang Wisuda, Sumbangan Peningkatan Kualitas Pendidikan (SPKP), dan lain-lain. Melalui penerapan UKT berarti bahwa hanya terdapat satu jenis pungutan biaya perkuliahan yang dikenakan kepada mahasiswa. Peraturan terbaru yang memayungi implementasi UKT adalah Peraturan Menteri Riset, Teknologi, dan Pendidikan Tinggi Republik Indonesia Nomor 22 Tahun 2015 Tentang Biaya Kuliah Tunggal dan Uang Kuliah Tunggal Pada Perguruan Tinggi Negeri di Lingkungan Kementerian Riset, Teknologi, dan Pendidikan Tinggi. UKT merupakan sebagian dari Biaya Kuliah Tunggal (BKT) yang bebankan kepada setiap mahasiswa berdasarkan kemampuan ekonominya. BKT merupakan seluruh biaya operasional pendidikan per mahasiswa per semester pada program studi tertentu. UKT ditetapkan berdasarkan BKT dikurangi biaya yang harus ditanggung oleh Pemerintah.
Salah satu aspek penting yang dimaksudkan dalam penerapan UKT adalah bahwa pembebanan biaya kuliah disesuaikan dengan kemampuan ekonomi dari setiap mahasiswa. Oleh karena itu, dalam penerapan UKT sebuah Perguruan Tinggi Negeri menetapkan beberapa kategori pungutan UKT, sehingga selain dapat mengakomodasi anggota masyarakat tidak mampu secara ekonomi untuk mengenyam pendidikan tinggi, juga target penerimaan Perguruan Tinggi Negeri untuk biaya operasional penyelenggaraan pendidikan juga dapat tercapai.

Dalam menentukan mahasiswa ke dalam kelompok UKT yang ada berdasarkan kemampuan ekonomi mahasiswa, beberapa hal yang perlu dilakukan adalah mengembangkan rincian kriteria yang ditujukan untuk menyaring (filter) dan mengelompokkan (classify) seorang mahasiswa ke dalam kategori-kategori UKT tersebut di atas berdasarkan kemampuan ekonominya dan yang terpenting adalah melibatkan keunggulan teknologi informasi dalam mengembangkan sebuah Aplikasi Sistem Penunjang Keputusan dalam Penentuan UKT Mahasiswa.

\section{Landasan Teori}

\subsection{Sistem Pendukung Keputusan}

Sistem Pendukung Keputusan (SPK) atau Decision Support System (DSS) adalah sebuah sistem yang mampu memberikan kemampuan pemecahan masalah maupun kemampuan 
pengkomunikasian untuk masalah dengan kondisi semi terstruktur dan tak terstruktur. Sistem ini digunakan untuk membantu pengambilan keputusan dalam situasi semi terstruktur dan situasi yang tidak terstruktur, dimana tak seorangpun tahu secara pasti bagaimana keputusan seharusnya dibuat (Turban, 2001).

SPK bertujuan untuk menyediakan informasi, membimbing, memberikan prediksi serta mengarahkan kepada pengguna informasi agar dapat melakukan pengambilan keputusan dengan lebih baik.

SPK merupakan implementasi teori-teori pengambilan keputusan yang telah diperkenalkan oleh ilmu-ilmu seperti operation research dan menegement science, hanya bedanya adalah bahwa jika dahulu untuk mencari penyelesaian masalah yang dihadapi harus dilakukan perhitungan iterasi secara manual (biasanya untuk mencari nilai minimum, maksimum, atau optimum), saat ini computer PC telah menawarkan kemampuannya untuk menyelesaikan persoalan yang sama dalam waktu relatif singkat.

Sprague dan Watson mendefinisikan Sistem Pendukung Keputusan (SPK) sebagai sistem yang memiliki lima karakteristik utama yaitu (Sprague et.al, 1993):

1. Sistem yang berbasis komputer.

2. Dipergunakan untuk membantu para pengambil keputusan.

3. Untuk memecahkan masalah-masalah rumit yang mustahil dilakukan dengan kalkulasi manual.

4. Melalui cara simulasi yang interaktif.

5. Dimana data dan model analisis sebagai komponen utama.

\subsection{Metode (MOORA)}

Metode Multi-Objective Optimization by Ratio Analysis (MOORA) adalah metode yang diperkenalkan oleh Brauers dan Zavadkas (2006). Metode yang relatif baru ini pertama kali digunakan oleh Brauers dalam suatu pengambilan dengan multi-kriteria. Metode MOORA memiliki tingkat fleksibilitas dan kemudahan untuk dipahami dalam memisahkan bagian subjektif dari suatu proses evaluasi kedalam kriteria bobot keputusan dengan beberapa atribut pengambilan keputusan (Mandal dan Sarkar, 2012). Metode ini memiliki tingkat selektifitas yang baik karena dapat menentukan tujuan dari kriteria yang bertentangan. Dimana kriteria dapat bernilai menguntungkan (benefit) atau yang tidak menguntungkan ( cost).

Metode MOORA banyak diaplikasikan dalam beberapa bidang seperti bidang manajemen, bangunan, kontraktor, desain jalan, dan ekonomi. Metode ini memiliki tingkat selektifitas yang baik dalam menentukan suatu alternatif. Pendekatan yang dilakukan MOORA didefinisikan sebagai suatu proses secara bersamaan guna mengoptimalkan dua atau lebih yang saling bertentangan pada beberapa kendala (Attri dan Grover, 2013).

Dalam aplikasinya metode MOORA dalam menyelesaikan masalah pemilihan supplier bahan kimia dan bioteknologi dengan menerapkan fuzzy dan MOORA. Model pengambilan keputusan yang dihasilkan mampu melakukan evaluasi terus menerus dalam penyelesaian masalah pemilihan dan evaluasi supplier (Seema et. al., 2012).

Metode MOORA terdiri dari lima langkah utama (Brauers and Zavadskas, 2006; Chakraborty, 2011; Gadakh, 2011; El-Santawy and Ahmed, 2012, Kalibatas, et al. 2008, Lootsma, 1999) sebagai berikut:

Langkah 1: langkah pertama adalah menentukan tujuan dan mengidentifikasi atribut evaluasi yang bersangkutan.

Langkah 2: langkah selanjutnya menampilakan semua informasi yang tersedia untuk atribut dalam bentuk matriks keputusan. $x$ adalah nilai kriteria masing-masing kriteria yang direpresentasikan sebagai matriks.

$$
x=\left[\begin{array}{cccc}
x_{11} & x_{12} & \cdot & x_{1 n} \\
x_{21} & x_{22} & \cdot & x_{2 n} \\
\cdot & \cdot & \cdot & \cdot \\
x_{m 1} & x_{m 2} & \cdot & x_{m n}
\end{array}\right]
$$

Langkah 3: Brauers et al. (2008) menyimpulkan bahwa denominator, pilihan terbaik dari akar kuadrat dari penjumlahan kuadrat dari setiap alternatif per atribut. Rasio ini dapat dinyatakan sebagai berikut.

$$
X_{i j}^{*}=\frac{x_{i j}}{\sqrt{\sum_{j=1}^{m} x_{i j}^{2}}}
$$

Rasio $x_{i j}$ menunjukkan urutan ke i dari alternatif pada kriteria ke j, m menunjukkan banyaknya jumlah alternatif dan $\mathrm{n}$ menunjukkan jumlah kriteria. Brauers et al. (2008) menyimpulkan bahwa untuk denominator, pilihan terbaik dari akar kuadrat dari penjumlahan kuadrat dari setiap alternatif per kriteria.

Langkah 4: untuk multi-objective optimization, hasil normalisasi adalah penjumlahan dalam hal pemaksimalan (dari atribut yang menguntungkan/ benefit) dan pengurangan dalam hal peminimalan (dari atribut yang tidak menguntungkan/ cost). Selanjutnya masalah optimasi menjadi: 


$$
y_{i}=\sum_{j=1}^{g} x_{i j}-\sum_{j=g+1}^{n} x_{i j}
$$

Dinama g adalah nilai kriteria yang akan dimaksimalkan, (n-g) adalah nilai dari kriteria yang diminimalkan, dan $\mathrm{Y}_{\mathrm{i}}$ adalah nilai dari penilaian normalisasi alternatif i terhadap semua atribut. Dalam beberapa kasus, sering mengamati beberapa kriteria yang lebih penting lainnya. memesan untuk memberikan lebih penting atribut, itu tersebut dilakukan dengan bobot yang sesuai (signifikan koefesien). Ketika bobot kriteria ini dipertimbangkan maka persamaan $\mathrm{Y}_{\mathrm{i}}$ adalah berikut

$$
y_{i}=\sum_{j=1}^{g} w_{j} x_{i j}-\sum_{j=g+1}^{n} w_{j} x_{i j}
$$

Dimana $\mathrm{W}_{\mathrm{j}}$ adalah bobot atribut $\mathrm{j}$.

Langkah 5: Nilai $Y_{\mathrm{i}}$ bisa Positif atau negatif tergantung dari jumlah maksimal (kriteria yang menguntungkan) dan minimal (kriteria yang tidak menguntungkan) dalam matriks keputusan.

\section{Metodologi Penelitian}

Pada bab ini menjabarkan tentang metode penelitian yang digunakan dan konsep dari pembuatan sistem, sehingga setiap tahap penelitian dapat dilakukan dengan tepat.

\subsection{Prototype Model}

Pada bagian ini akan dibahas metodologi yang akan digunakan dalam penelitian ini yaitu Pengembangan Sistem Penunjang Keputusan Penentuan UKT Mahasiswa dengan Menggunakan Metode MOORA. Metode yang digunakan dalam penelitian ini adalah metode Prototype.

Proses yang terdapat dalam metode Prototype ini akan dijelaskan pada Gambar 3.1 sebagai berikut. (Sumber : Debby, dkk, 2014)

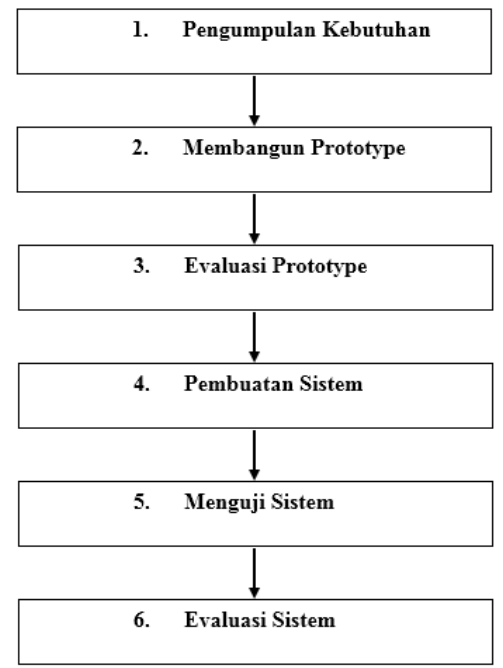

Gambar 1. Prototype Model

\section{Analisa dan Perancangan}

\subsection{Bisnis proses}

Proses yang digambarkan pada Gambar 4.1 admin akademik mengunggah data maba ke Sistem Informasi penentuan UKT mahasiswa bisa login menggunakan nomortes dan password sesuai dengan saat mereka mendaftar untuk mengisi data kemampuan ekonomi mahasiswa sesuai batas waktu yang telah ditentukan, selanjutnya tim pengambil keputusan dengan mengakses sitem tersebut menentukan rentang skor masing masing ukt, penentuan rentang skor ini digunakan untuk menampilkan informasi kelompok UKT masingmasing mahasiswa. Data tersebut digunakan oleh tim pengambil keputusan untuk menentukan kelompok UKT masing masing mahasiswa.

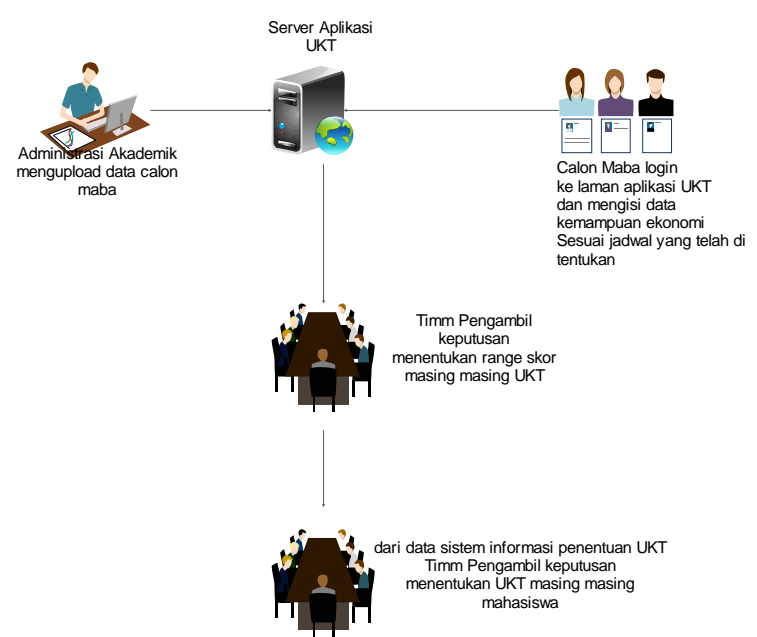

Gambar 2. Proses penentuan UKT 


\subsection{Use Case}

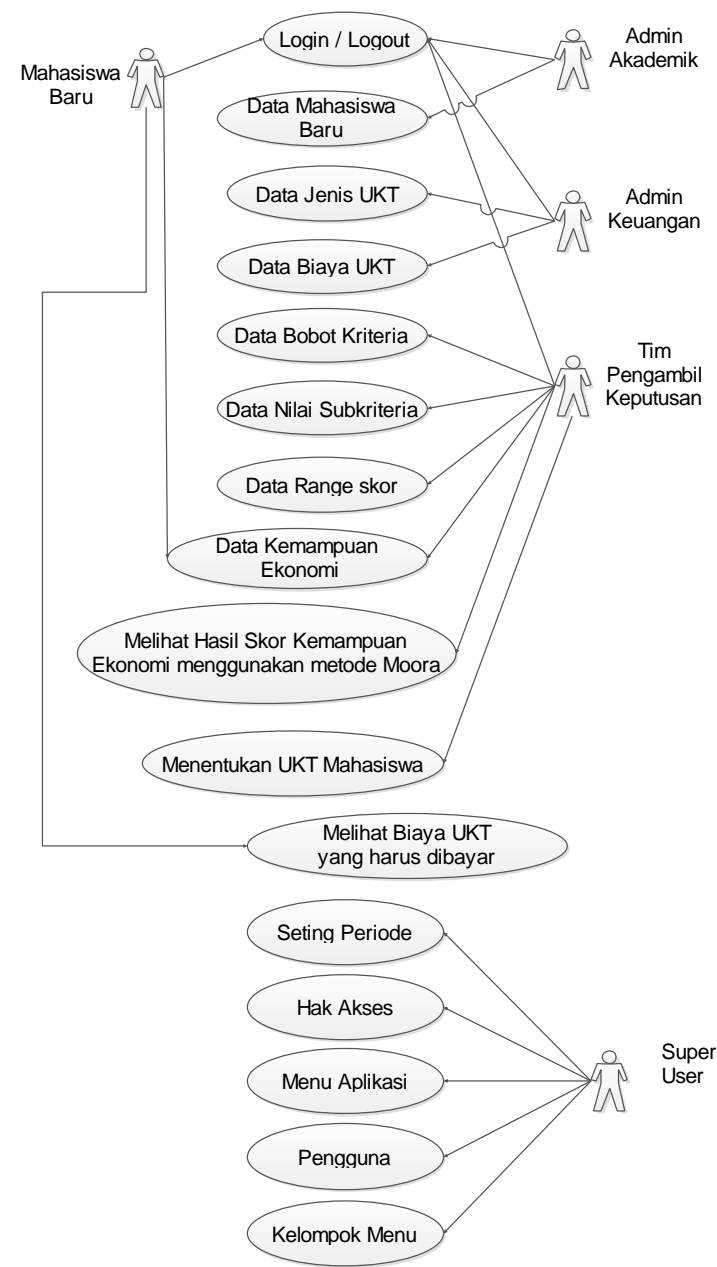

Gambar 3. Desain usecase Sistem Penunjang

Keputusan Penentuan UKT Mahasiswa

Admin Akademik mempunyai hak akses untuk login, CRUD (Create Read Update Delete) data Jalur masuk, data mahasiswa baru, data progrm studi dan logout.

Admin Keuangan mempunyai hak akses untuk login, CRUD (Create Read Update Delete) data Jenis UKT, data biaya kuliah dan logout.

Tim Pengambil Keputusan mempunyai hak akses untuk login, CRUD (Create Read Update Delete) data Sub Kriteria, data bobot Kriteria, Range Skor UKT., Melihat Hasil Perangkingan. RU (Read Update ) data kemampuan ekonomi mahasiswa dan logout.

Super User mempunyai hak akses untuk login, CRUD (Create Read Update Delete) data periode, Hak Akses, Menu Aplikasi, Pengguna, Kelompok Menu, Menu Hak akses dan logout.

Mahasiswa mempunyai hak akses untuk login, menambah dan melihat data dokumen kemampuan ekonomi mahasiswa yang bersangkutan saja, logout.

\subsection{Flow chart Metode Penelitian}

Dalam penelitian ini bobot kriteria, nilai subkriteria dan data kemampuan ekonomi seluruh mahasiswa yang akan di tentukan ukt nya adalah satu kesatuan data yang akan diproses dalam Sistem Penunjang Keputusan penentuan UKT Mahasiswa menggunakan medote MOORA. Tim pengambil keputusan baru dapat menentukan nilai range masing masing kelompok UKT setelah semua data kemapuan ekonomi mahasiswa tiap periode dan jalur masuk terisi selama batas waktu yang ditentukan.

Pada Gambar 4.3 di bawah adalah gambaran umum dari flowchart sistem Sistem Penunjang Keputusan penentuan UKT Mahasiswa menggunakan medote MOORA.

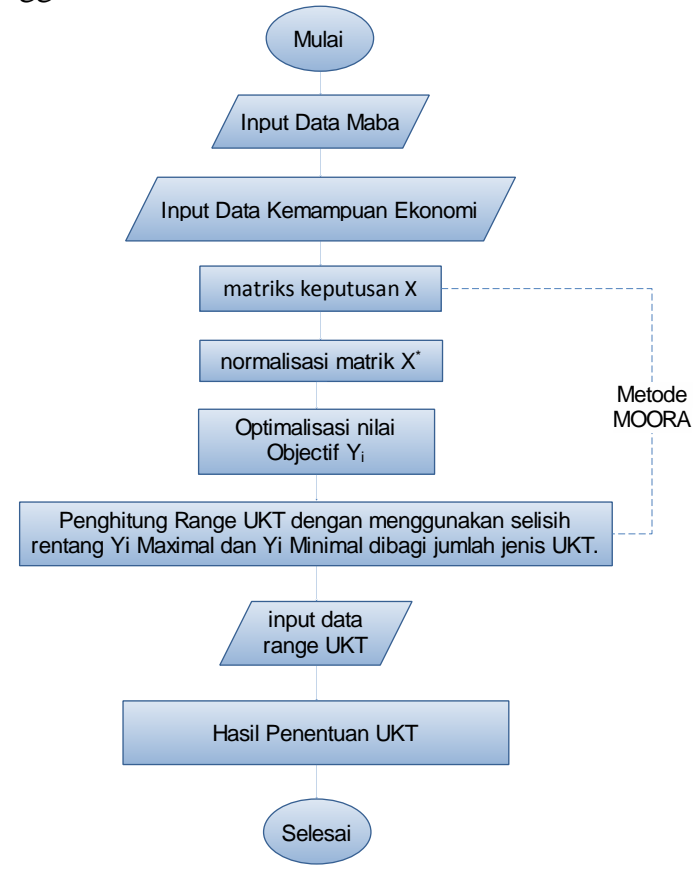

Gambar 4 Gambaran umum flowchart sistem

\section{Implementasi}

\subsection{Implementasi Basis Data}

pada Sistem Penunjang Keputusan Penentuan Uang Kuliah Tunggal (UKT) Mahasiswa Politeknik Negeri Malang relasi tabel dapat dilihat pada gambar 5.1 Relasi antar tabel. 


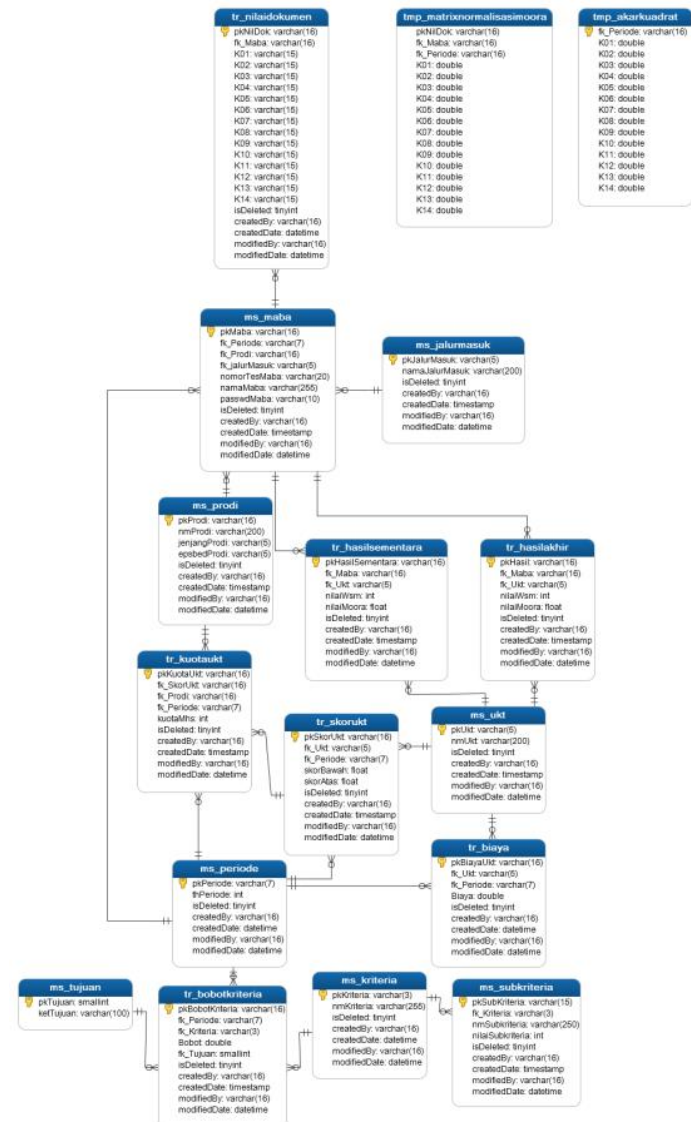

Gambar 5. Relasi antar table

\subsection{Implementasi Sistem}

Implementasi antar muka merupakan proses pengubahan sistem yang telah dirancang kemudian diterapkan dalam program..

\subsubsection{Tampilan Halaman Login}

Tampilan awal aplikasi pada halaman login yang terdiri dari username, password dan button login . Gambar 5.2

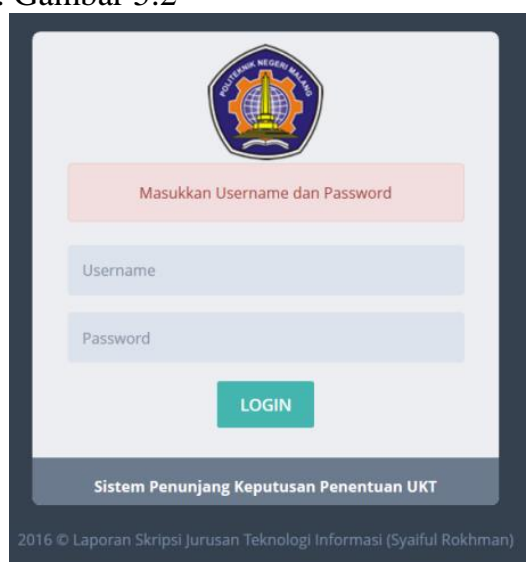

Gambar 6. Halaman Login

\subsubsection{Implemetasi Halaman Mahasiswa}

Tampilan Form Kemampuan Ekonomi mahasiwa untuk login sebagai kelompok pengguna mahasiswa dapat dilihat pada gambar 5.3 Form Pengisian data kemampuan ekonomi mahasiswa .

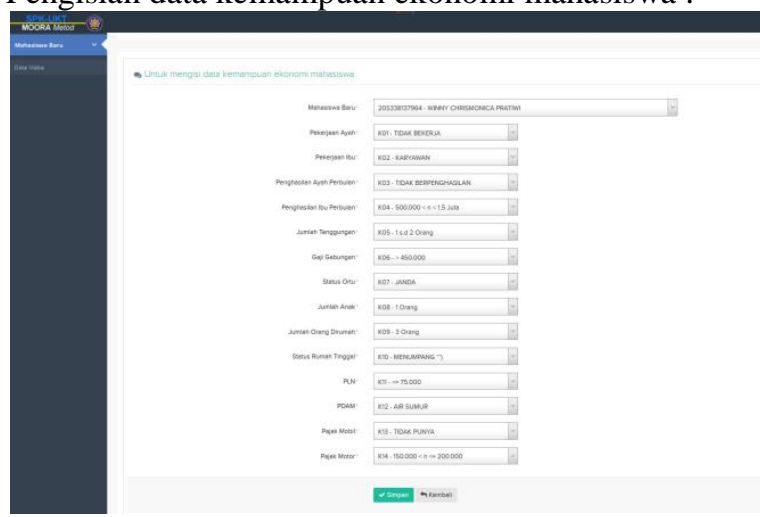

Gambar 7. Form Pengisian data kemampuan ekonomi mahasiswa

\subsubsection{Kelola Data Kemampuan Ekonomi Mahasiwa}

Tampilan Data Kemampuan Ekonomi Mahasiwa pada gambar 5.3 hanya bisa dilihat oleh kelompok tim pengambil keputusan, pada form ini ditampilkan daftar nilai kemampuan ekonomi mahasiswa.

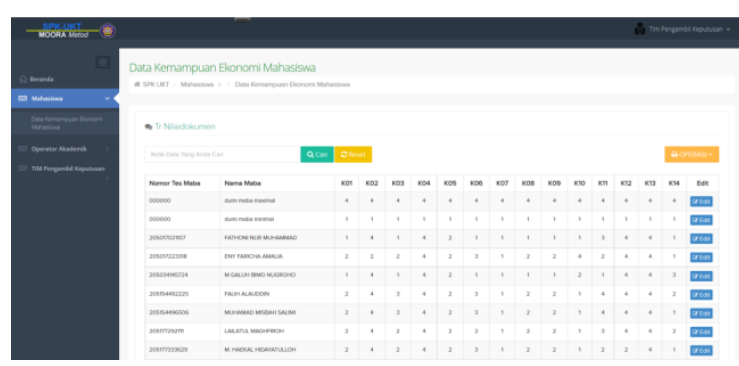

Gambar 8. Data Kemampuan Ekonomi Mahasiwa

\subsubsection{Kelola Data Kemampuan Ekonomi Mahasiwa}

Tampilan Data Kemampuan Ekonomi Mahasiwa pada gambar 5.3 hanya bisa dilihat oleh kelompok tim pengambil keputusan, pada form ini ditampilkan daftar nilai kemampuan ekonomi mahasiswa.

\section{Pengujian dan Pembahasan}

\subsection{Uji Coba}

Setelah proses pengimplementasian pada perancangan sistem, tahapan selanjutnya adalah proses pengujian dan analisis hasil implementasi. Proses pengujian dilakukan dengan 3 cara, yaitu uji coba fungsional, uji coba perhitungan manual, dan uji coba perhitungan sistem. Pengujian yang dilakukan bertujuan untuk memastikan bahwa sistem yang dibangun telah berjalan sesuai yang diharapkan.

\subsubsection{Uji Coba Fungsional}

Uji coba fungsional digunakan untuk mengetahui apakah sistem yang dibangun sesuai 
dengan yang kebutuhan pengguna. Uji coba ini dilakukan menggunakan blackbox. Uji coba fungsional dikatakan berhasil apabila fungsi yang ada pada sistem pendukung keputusan penentuan UKT mahasiswa sesuai dengan yang diharapkan pengguna.

\subsubsection{Uji Coba Perhitungan Manual}

Perhitungan manual dengan metode MOORA menggunakan 30 data sample kemampuan ekonomi mahasiswa yang didapatkan dari bagian akademik Politeknik Negeri Malang. Selain itu di masukan juga 2 data default dengan 1 data bernilai maximal dan 1 data bernilai minimal Berikut ini adalah flowchart perhitungan metode MOORA yang akan digambarkan pada Gambar 6.2

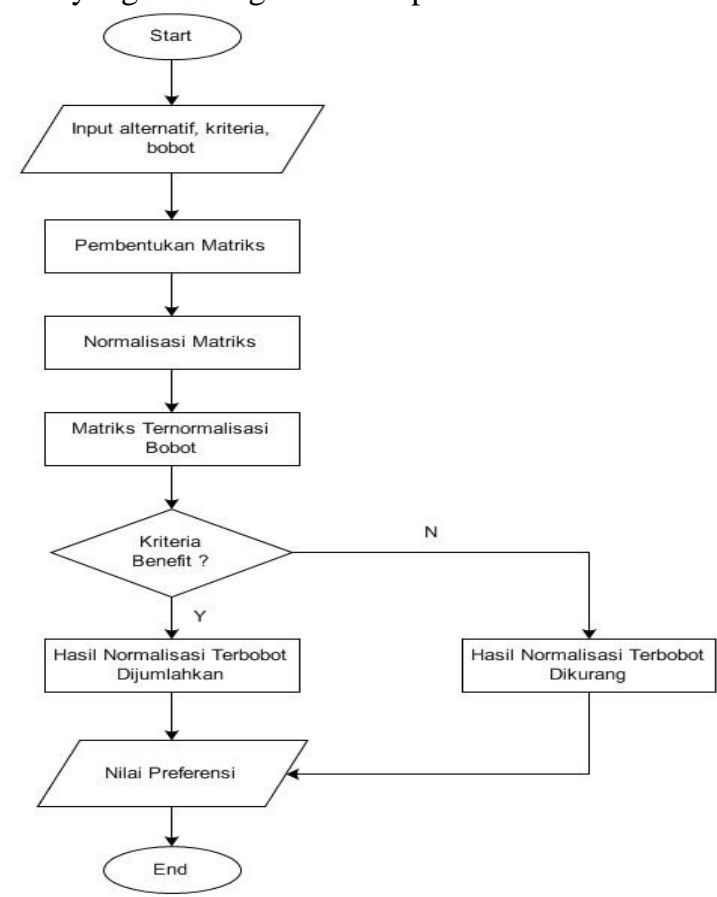

Gambar 9. Flowchart Perhitungan Metode MOORA

\subsection{Kesimpulan}

Berdasarkan penelitian yang dilaksanakan oleh penulis pada Sistem Penunjang Keputusan Penentuan Uang Kuliah Tunggal Mahasiswa Politeknik Negeri Malang menggunakan metode MOORA, dapat ditarik kesimpulan sebagai berikut

1. Dengan menggunakan metode MOORA tingkat presisi penghitungan nilai rentang antar kelompok UKT lebih baik daripada menggunakan cara penghitungan sebelumnya (karena range tiap UKT sama).

2. Metode MOORA dapat diimplementasikan dalam penentuan UKT Mahasiswa ini dapat ditunjukan pada Tabel 6.10 Perbandingan Hasil Perangkingan, dengan menggunakan metode ini pendapatan Uang Kuliah Tunggal bisa lebih besar di banding menggunakan cara penghitungan sebelumnya.

3. Informasi penentuan UKT dapat dilakukan setelah jadwal proses entry data kemampuan ekonomi mahasiswa ditutup.

\subsection{Saran}

Untuk meningkatkan keakuratan Pengembangan Sistem Penentuan Uang Kuliah Tunggal Mahasiswa Politeknik Negeri Malang kedepannya diharapakan untuk mempertimbangkan hal-hal di bawah ini:

1. Perlu ada metode lain yang digunakan untuk membandingkan perangkingan dan penentuan Uang Kuliah Tunggal berdasarkan kemampuan ekonomi mahasiswa.

2. Perlu adanya pembobotan pada masing masing kriteria.

\section{Daftar Pustaka}

Ahmednagar, Maharashtra - 422 608, India 2011. Application of MOORA method for parametr ic optimization of milling process. Internation al Journal Of Applied Engineering Research, Dindigul Volume 1, No4, 2011

Alvydas BALEŽENTIS1, Tomas BALEŽENTIS2, Willem K.M. BRAUERS3,2012. MULTIMOORA-FG: A Multi-Objective Decision Making Method for Linguistic Reasoning with an Application to Personnel Selection, INFORMATICA, 2012, Vol. 23, No. 2, 173-190

Ani sholihah, 2014. Sistem pendukung keputusan penentuan Uang Kuliah Tunggal (UKT) dengan metode nä̈ve bayes (studi kasus di universitas trunojoyo madura), TRUNOJOYO-Tugas Akhir-5657.

Edmundas Kazimieras Zavadskas, 1 Jurgita Antucheviciene, 1 Seyed Hossein Razavi Hajiagha, 2 and Shide Sadat Hashemi 3, 2015. The Interval-Valued Intuitionistic Fuzzy MULTIMOORA Method for Group Decision Making in Engineering. Hindawi Publishing Corporation Mathematical Problems in Engineering Volume 2015, Article ID 560690, 13 pages.

WKM Brauers, EK Zavadskas - Control and Cybernetics, 2006. The MOORA method and its application to privatization in a transition economy

Suharsono, Herman Mawengkang, Poltak Sihombing, Basrah Nasution. 2014. Metode MOORA Untuk Menentrukan Jurusan. Seminar Nasional Inovasi dan Teknologi Informasi 2014 (SNITI 2014).

Pedoman Penulisan Laporan Akhir dan Skripsi Final Versi2. 2016. Malang: Politeknik 
Negeri Malang.

Turban, Efraim \& Aronson, Jay E. 2001. Decision Support Systems and Intelligent Systems. 6th edition. Prentice Hall: Upper Saddle River, NJ.

Peraturan Menteri Riset, Teknologi, dan Pendidikan Tinggi Nomor 22 Tahun 2015 tentang Biaya Kuliah Tunggal dan Uang Kuliah Tunggal pada Perguruan Tinggi Negeri di Lingkungan Kementerian Riset, Teknologi, dan Pendidikan Tinggi.

Sparague, R. H. and Watson H. J. 1993. Decision Support Systems: Putting Theory Into Practice. Englewood Clifts, N. J., Prentice Hall. 